\title{
SKRIFTLIG INTERAKTION I SKOLEN
}

\author{
Jesper Tække \\ Institut for Kommunikation og Kultur \\ Center for internetforskning \\ Aarhus Universitet : www.jespertaekke.dk \\ imvjet@cc.au.dk \\ Twitter: @taekke \\ Michael Paulsen \\ Institut for Kulturvidenskaber \\ Syddansk Universitet: www.michaelpaulsen.dk \\ mpaulsen@sdu.dk \\ Twitter: @forskerMP
}

\begin{abstract}
Artiklen omhandler, hvorvidt den nye skriftlige interaktion, kendt fra sms og sociale medier, udviser et fagligt og socialt potentiale, når det gælder undervisning. Først udvikler artiklen begrebet om skriftlig interaktion ud fra en kritisk diskussion af Niklas Luhmanns systemteoretiske kommunikationssociologi. Herefter undersøges empirisk om skriftlig interaktion gennem digitale medier kan rumme et fagligt og socialt potentiale. I artiklen argumenteres for, at undervisning hidtil primært er blevet praktiseret som mundtlig interaktion inden for klasserummets fire vægge, repræsenterende skolens omverden gennem bl.a. lærebøger. I et digitaliseret samfund bliver det imidlertid muligt at skabe undervisning, hvor undervisningsinteraktion i højere grad kan være både skriftlig og mundtlig, og dermed give flere interaktionsmuligheder end tidligere, samtidig med at en del af denne interaktion kan ske med omverden.
\end{abstract}

\section{Indledning}

Undervisning er en social aktivitet, der kræver meningsfuld interaktion og reproesentation af betydningsindhold (Luhmann 2006, Biesta 2014). Repræsentation kræves, fordi undervisningen skal danne eleven til andre dele af samfundet end blot den del, som udgør undervisningen. Læreren må derfor 
i undervisningen repræsentere undervisningens omverden. Fordi der er forskel på læreren og eleverne ift. deres forhold til undervisningens omverden, fx deres viden herom, kræves interaktion, så begge kan formidle til hinanden, hvordan de forstår og ikke forstår det, som undervisningen omhandler og går ud på. Det samme gælder, hvis elever med forskellig socialbaggrund skal samarbejde og deltage i en og samme undervisning. Når nye generationer kommer til verden, er de skrøbelige og ufærdige og kan både præges og vil dø eller forarmes, hvis der ikke drages omsorg for dem. Undervisning har med dette at gøre, hvor socialisering ikke i sig selv er tilstrækkeligt. Mulighederne for at undervise, dvs. for at kombinere interaktion og repræsentation, er imidlertid begrænsede af, hvilke medier for kommunikation og erkendelse et samfund baserer sig på. Således har vi op gennem historien bevæget os gennem forskellige mediesamfund (Finnemann 2005), hvor det første kommunikationsmedie, talesproget, muliggjorde en social selvreference i den forstand, at det med talesproget blev muligt at kommunikere om kommunikation (Luhmann 2000). Talesproget skabte derfor forudsætningerne for samfundet og derved for mennesket som menneske.

Med et samfund kun baseret på talesprog falder interaktion og repræsentation sammen - et og samme medie skal "klare det hele". Idet skriftsproget opfindes, kan "mere varig" repræsentation "udlejres" og opbevares i skriften, mens talen kan frigøres til dialogiske formål. Således behøver samfundets hukommelse ikke længere fikseres i talen (som remser osv.), men kan fagliggøres i skriftens fastholdende form. Dette dog ikke med ét slag, men efterhånden som menneskene får mulighed for at lære at læse og skrive, hvilket udgør en langstrakt civilisationshistorisk periode på flere tusinde år, der endnu ikke er tilbagelagt. Skriften må nemlig læres, kommer ikke af sig selv, som talesproget, der typisk kan tilegnes gennem den blotte socialisering (i hjemmet $\mathrm{fx}$ ) og forblev endog altovervejende forbeholdt bestemte grupper, fx græsk og romersk overklasse, indtil trykkepressen fremkom i 1440'erne. Først i 1814 fik vi i Danmark en skolelov, hvorefter alle danske børn skulle i skole for at lære at læse og skrive (Drejer 2014). Det var dannelses- og oplysningsprojektet, der i kølvandet på opfindelsen af trykkekunsten var nået til Danmark. Herunder var skoleloven udtryk for, at verden var blevet mere kompleks og at boglig dannelse antoges at være påkrævet for at agere dueligt i samfundet. Således blev det skolesystem, vi kender i dag, opbygget i et mediesamfund der havde talesprog, skriftsprog og trykmediet til sin rådighed. Grundlæggende blev det bygget på den opfattelse, at undervisning skal finde sted i et fra resten af verden afsondret rum (nemlig klasseværelset eller skolestuen), som en mundtlig interaktion mellem lærer og elever (Luhmann 2006). For at eleverne gennem denne kunne dannes til den virkelige verden med dens muligheder og udfordringer, lå det også i denne forståelse, at verden uden for skolestuen skulle reprosenteres gennem medier som lærebogen, tavlen, den vidende lærer og senere teknologier som projek- 
tor, videoapparat og lign. ${ }^{1}$ Denne opfattelse af undervisning har holdt ved helt frem til den digitale revolution, som vi i denne artikel vil forstå nærmere fordi først denne åbner op for en grundlæggende anderledes ramme omkring, hvad undervisning kan være (Tække \& Paulsen 2016). Vores pointe vil være, at med det digitale bliver det (i langt højere grad end tidligere) muligt at flette repræsentation og interaktion sammen igen, på en måde som det i tidernes morgen var i talesproget, men nu inkluderende både tale og skrift og dermed med kompleksitetsgevinster til følge.

Artiklen undersøger, om og hvordan skolen kan opnå disse kompleksitetsgevinster ved at indlemme skriftlig interaktion. Den falder i to dele, hvor den første søger at fremstille et teoretisk grundlag, mens anden halvdel med støtte i forskningsprojektet Socio Media Education analyserer et aktuelt forsøg på at bruge digitale medier til at inkludere skriftlig interaktion i skolens undervisning.

\section{Teoretisk udlægning af undervisningens forudsætninger}

Niklas Luhmann udviklede en omfattende samfundsteori fra 1960'erne og frem til sin død i 1998. Teorien rummer et bud på, hvordan man kan forstå samfundets undervisning (Luhmann 2006). Som vi ser det, rummer dette bud et rimeligt træffende billede af, hvorledes man hidtil har opfattet undervisning. Imidlertid giver selvsamme bud anledning til at genoverveje, om et digitalt baseret samfund giver en anderledes ramme omkring undervisning, så undervisning i dag må forstås delvist anderledes. Vi vil først udlægge, hvordan Luhmann forstod undervisning. Dette gennem at redegøre for, hvad undervisning ifølge Luhmann grundlæggende er for noget. Således redegør vi for, at undervisning er 1) kommunikation, 2) nærmere bestemt interaktion, 3) nærmere bestemt (især) mundtlig interaktion 4) der baserer sig på ibrugtagning af kommunikationsmedier og desuden 5) finder sted $i$ skoleklasser afgrænset fra resten af samfundet. I forlængelse heraf genovervejer vi, hvorvidt undervisning - især i det nye mediemiljø, der også inkluderer digitale medier - også kan være skriftlig interaktion (og hertil hvilke faglige og sociale potentialer der kan være herved, hvilket vi dog først for alvor fordyber os i, i artiklens tredje hovedafsnit, da det kræver en mere empirisk analyse).

\subsection{Undervisning er kommunikation}

Ifølge Luhmann består sociale systemer - og dermed også undervisning - kun i og af kommunikation, og han er berømt og berygtet for aforismen om, at kun kommunikation kommunikerer. Kommunikation defineres som enheden af tre selektioner, nemlig selektion af information, meddelelse og forståelse (Luhmann 1999:72, 190). Information defineres ud fra Bateson som en forskel, der gør en forskel (Luhmann 2000:79). At udtale sig, eller blot at sige noget om verden, er at acceptere, at der er viden om verden, hvorfor en udtalelse 
altid er at markere en forskel til, hvad der ellers ville kunne siges (ibid.:182). Hvis andre personer skal blive opmærksom på den information, der er selekteret, må man meddele den, fx ved at bruge sin stemme. Information og meddelelse kan ses på linje med Saussures begreber om betegnet og betegnende (Saussure 1966:66). Luhmann (2000:181-182) opfatter forståelse som en skelnen mellem information og meddelelse. Man lader fx ikke en bankelyd på en dør blot være rytme eller støj, man skelner informationen (at nogen gerne vil ind) fra meddelelsen (lyden). Forståelse er således distinktionen mellem information og meddelelse. Med enheden af alle tre selektioner konstitueres en elementarkommunikation. Videre forløber al kommunikation som kæder af elementarkommunikationer, der knytter an bagud i tid. I denne proces accepteres og negeres meningsforslag, hvorved der etableres en meningsgrænse, der dels distingverer forskellige sociale systemer fra hinanden og dels giver dem anknytningssandsynlighed internt (man ved, om hvad og hvordan man skal meddele sig).

\subsection{Undervisning er interaktion}

Luhmann skelner mellem tre typer sociale systemer: Interaktionssystemer, organisationer og selve samfundet, hvor (det moderne) samfund igen beskrives som uddifferentieret i funktionssystemer, der er lukkede i sagsdimensionen (økonomi er kun om økonomi) og åbne i socialdimensionen (alle kan deltage i økonomien). Samfundet defineres som det altomfattende sociale system, der omfatter alle anknyttede kommunikationer. Heroverfor står organisationer, der kan forstås som beslutningssystemer, der kræver medlemskab og således er lukkede i socialdimensionen, men åbne i sagsdimensionen (de må både kunne kommunikere om økonomi, jura, videnskab og meget andet). Luhmann definerer den tredje type socialsystem, nemlig interaktionssystemer, således, at det er de bidragende personers gensidige nærhed og iagttagelse der er afgørende: "Interaktionssystemer kommer i stand derigennem, at tilstedeværende gensidigt iagttager hinanden. (...) Som eksempler på interaktionssystemer kan man nævne: Familiens fælles indtagelse af mad (ikke familien selv), det enkelte regeringsmøde (ikke regeringen som sådan), det at stå i kø ved billetlugen, et slag whist, en masseforsamling, et slagsmål, en taxitur." (Luhmann 1975 op. cit.:10. Her citeret fra Qvortrup 1993:33). Luhmann er her tæt på Goffmann, der definerer interaktion som: "the reciprocal influence of individuals upon one another's actions when in one another's immediate physical presence." (Goffman, 1959:26). For Luhmann er interaktioner flygtige og kræver tilstedevær og gensidig iagttagelse. De er den mest oprindelige form for kommunikation og kan foregå nonverbalt, om end det først er med talesproget, at de udvikler sig til selvrefererende kommunikationssystemer, der, mens nærheden varer ved, opbygger en egen historie, der siden er med til at regulere dem. 
Interaktionssystemer uddifferentierer sig således gennem nærhed mellem dem, der bidrager. Netop denne konstituering muliggør muligheden for undervisning forstået som nærhed mellem elever og lærer, der bidrager til en fælles samtale ( $\mathrm{fx}$ : læreren kommer ind og siger noget til eleverne i en klasse, der responderer, og et fælles momentant nærvær opstår, så længe lektionen varer ved, og man gensidigt retter opmærksom mod hinandens ytringer). Spørgsmålet er nu om interaktion kan etableres uden mundtlig tale.

\subsection{Undervisning som skriftlig interaktion?}

Ovenstående forståelse af undervisning som interaktion kan man tolke som en antagelse om, at der kun sker undervisning, når lærere og elever er fysisk tilstedeværende for hinanden, fx i det samme klasselokale. Kravet om fysisk tilstedevær er dog problematisk, da det så for eksempel ikke kan betegnes som interaktion at tale i telefon, med mindre det antages, at man er fysisk tilstede i en telefonsamtale - stemmerne er jo fx nærværende for hinanden, og stemmen er en del af kropsligheden - svarende til fx en samtale mellem to blinde. Vi vil på den baggrund argumentere for, at interaktionsbegrebet må have en bredere betydning end hos Luhmann og Goffman, således at kommunikation i kommunikationsmedier som $\mathrm{fx}$ en telefon godt vil kunne betegnes som interaktion, men også således at fx skriftlig chat kan iagttages som interaktion (se Tække 2002; 2006b). Således vil vi definere interaktion som den type kommunikation, hvor alter og ego gensidigt iagttager hinandens ytringer og responderer herpå (og dermed forholder sig til og svarer på hinandens distinktioner mellem information og meddelelse). For at dette kan lade sig gøre, må der kunne ske en eller anden form for turtagning mellem bidragyderne (omend der ikke er noget krav om linearitet, se Tække 2006b). Nogle medier og situationer giver stor mulighed for dette, andre mindre mulighed eller ingen mulighed. En situation, hvor alter og ego behersker samme talesprog, fx dansk, og mødes ansigt til ansigt, giver stor mulighed. Her kan alter og ego skiftevis respondere $p a ̊$ hinandens ytringer. Hvis alter og ego befinder sig på hver sin side af kloden, men kan skrive breve til hinanden, kan de også skiftes til at respondere til hinanden på hinandens ytringer, men mere begrænset, for så vidt der kan gå lang tid, før hvert brev når frem, og for så vidt at skriftsproget mangler de kropslige konnotationsmuligheder, som en ansigt-til-ansigt samtale giver. Endelig kan der også være situationer, hvor der er tale om kommunikation, men ikke interaktion. Fx kan vi i dag ikke henvende os til Platon, men godt konsultere Platons tekster og dermed kommunikere videre om disse ud fra disse.

I forlængelse heraf vil vi argumentere for, at det er muligt at skabe skriftlige interaktionssystemer i nye medier som Twitter og Facebook, herunder genindlejre sociale hensyn, der tidligere primært blev "løst" mundtligt og kropsligt, gennem bl.a. interfaces og pixel emoji. Der er dog stadig kun en svagt 
udviklet ytringskultur og dannelse resulterende $i$, at de vide muligheder for at interagere i mange tilfælde resulterer i fornærmelser og krænkelser (Jakobsen 2016). Samtidig giver de nye skriftlige interaktionsmedier vide muligheder for at gøre noget sammen på nye måder (social organisering, netværk, koordinering mv.). Mange af disse muligheder er dog kun svagt udviklede og understøttede af adækvate normer. Disse vanskeligheder er kendt fra mediehistorien, hvor tidligere medier også gav vanskeligheder i begyndelsen, fx trykketeknologien med efterfølgende tolkningskrige og en kun langsom udvikling af dannelse, ytringskultur, ytringsansvar og i takt hermed fremvoksende ytringsfrihed (Jakobsen 2016). Et andet eksempel er fjernsynet med følgende fald af autoriteter (Meyrowitz 1985). Pointen er, at de gamle normer, indstillet på en informationssituation hørende til et tidligere mediemiljø, bliver inadækvate og ikke længere virker som hensigtsmæssige sociale færdselsregler, men ikke desto mindre kun langsomt udskiftes (Meyrowitz 1985; Tække og Paulsen 2016).

I relation til undervisning vil vi sige, at Luhmanns opfattelse af interaktion lægger op til at iagttage alt, hvad der foregår mundtligt mellem elever og lærere i et klasselokale som undervisning. Dette udelukker ikke, at skriftlige medier også indgår, fx tavler, hæfter og plancher. Men den betydning, som repræsenteres i disse, afgrænses (dvs. accepteres og negeres) gennem den mundtlige interaktion (inklusive nonverbalt kropssprog). Dvs. de primært fungerer som reproesentationsmedier. Med den brede opfattelse af interaktion, vi har udlagt ovenfor, åbnes imidlertid op for at iagttage også skriftlig interaktion, fx hvis lærere og elever chatter sammen, men er fysisk forskellige steder, som undervisning. Dette kunne også lade sig gøre, før de digitale mediers indtog, fx i en telefon, men var undtagelser snarere end reglen, hvorfor det også i Luhmanns måde at opfatte undervisning på, udgrænses som særtilfælde af mindre vigtighed.

\subsection{Interaktivitet}

For videre at skelne mellem forskellige kommunikationsmediers forskellige mulighedsrum for interaktion og samhandlen (mundligt og skriftligt) vil vi - før vi går videre - udfolde begrebet interaktivitet. Interaktivitet er et begreb for håndtering af teknologi, mens interaktion er et sociologisk begreb for den reciprokke udveksling af ytringer mellem mennesker (Sutton 1999, Jensen 1999). Inspireret af Bordewijk og Kaams kan der med Jensen (1999) skelnes mellem transmissionel, konversationel, konsultativ og registrerende interaktivitet. Transmissionel interaktivitet betyder, at mediets potentialitet kun giver rum for envejskommunikation, hvad enten der er tale om én til én eller én til mange kommunikation. Konversationel interaktivitet betyder, at mediet giver rum for interaktion, hvor alle, der kan håndtere mediet og accepteres socialt, kan bidrage til kommunikationen i det. Et sådant medies direktional- 
itet begrænser således ikke den enkeltes muligheder for at bidrage, men retten til at bidrage kan være begrænset, for eksempel på Facebook, hvor man kan fratage "venner" retten til at kommentere på ens væg. Konsultativ interaktivitet vil sige, at man i et medie kan hente, se, læse, høre etc. 'information'. Informationen lagres af andre, men man kan hente den, når man vil, som det eksempelvis ses på Youtube. Også her kan der være tekniske muligheder for at diskriminere mediebrugeren. Registrerende interaktivitet vil sige, at mediebrugeren har informationen, som så kan indføres og viderebehandles af andre, der dog er afhængige af, at mediebrugeren meddeler sig, hvilket denne kan være socialt forpligtet til, fx ved udfyldelsen af selvangivelse online.

Digitale medier tilgængeliggør alle fire former for interaktivitet som immanente automatiserede funktionaliteter. Den transmissionelle finder man $\mathrm{fx}$ ved remediering af $\mathrm{tv}$, radio og avis i digitale medier. Den konversationelle finder man $\mathrm{fx}$ i chat. Den konsultative finder man $\mathrm{fx}$ i søgemaskiner. Og den registrerende finder man, fx når web-udbydere og sociale medier benytter logfiler, de såkaldte cookies, der registrerer tilgængelige data om brugeren, som $\mathrm{fx}$ hvilke websider der er sendt. De indsamlede informationer kan lagres, bearbejdes og, udover at kortlægge den enkelte brugers færden og vaner, benyttes til udarbejdelse af statistisk materiale (for uddybning: se Tække 2006b).

Som vi vender tilbage i vores empiriske analyse i afsnit 3 , så betyder det, at digitale medier har ret omfattende muligheder for interaktivitet, at de også rummer et ret omfattende potentiale i relation til undervisning. Vores pointe for indeværende er dog blot den generelle, at forskellige kommunikationsmedier rummer forskellige muligheder for interaktivitet, og at man må se nærmere på disse for at forstå deres undervisningspotentiale, for så vidt undervisning altså forstås som interaktion i den brede forståelse vi har udlagt ovenstående.

Lad os gøre status: Vi har nu redegjort for, hvordan undervisning kan forstås som interaktionssystemer, opfattet som en særlig form for kommunikationssystemer, der kræver, at alter og ego gensidigt responderer på hinandens ytringer, samt at dette i princippet også vil kunne realiseres i digitale skriftmedier. Hermed har vi vel at mærke endnu ikke sagt noget om, hvad der evt. vindes eller går tabt ved en sådan realisering frem for en realisering i fx et fysisk mundligt baseret møde i et klasselokale. Som et foreløbig lille skridt i retning af at kunne fremanalysere sådanne forskelle har vi inddraget begrebet interaktivitet, der åbner for at iagttage fire forskellige kommunikative funktioner, som kommunikationsmedier i større eller mindre omfang understøtter eller slet ikke understøtter. Før vi vender os mod en sådan analyse, vil vi dog først skitsere, hvad Luhmann siger om den samfundsmæssige kontekst, undervisning foregår $\mathrm{i}$. 


\subsection{Den samfundsmæssige kontekst for undervisning}

Ifølge Luhmann (2006) er uddannelsessystemet et uddifferentieret funktionssystem på linje med det politiske system, retssystemet og det økonomiske system. Uddannelsessystemet har sit eget symbolsk generaliserede kommunikationsmedie, som Luhmann (1993) definerede som barnet. Det er barnet, som lærerne taler om, når de diskuterer undervisning. Luhmann (2006) ændrer definitionen til livsforløb i stedet for barnet, for at indfange diskursen om livslang læring. Paulsen og Qvortrup (2007) har siden foreslået at definere uddannelsessystemets medie til at være loering. Systemets binære kommunikationskode defineres af Luhmann som bedre eller dårligere formidling. Som kontingensformel peger Luhmann på dannelse som det formningsideal, man sigter på i uddannelse. Eleven må formes til at kunne forme sig selv, bl.a. med henblik på med tiden at kunne og ville deltage mere og bedre i samfundet (Tække og Paulsen 2014). Undervisningssystemet har også en refleksionsteori bestående i pædagogik henholdsvis didaktik, der hjælper undervisere til at reflektere over, hvordan de kommunikative selektioner i klasselokalets interaktionssystem kan øge mulighederne for succesfuld undervisning.

Selve skolerne befinder sig ifølge Luhmann (2006) på det organisatoriske plan. Organisationer er bslutningssystemer, der beslutter, hvordan undervisningskoden skal fortolkes og udmøntes, samt hvilke refleksionsteorier der skal inspirere og forme undervisningen. Forskellige skoler har forskellige programmer for at organisere undervisningen. Eksempler er, hvor mange elever der skal være i hver klasse, hvilken type lærere der skal ansættes, hvor mange møder der skal holdes, hvor mange råd og teams der skal nedsættes etc. Som organisation beslutter skolen beslutninger, der virker som beslutningspræmisser for lærernes undervisning (herunder ikke-beslutninger, som når skolen beslutter at overlade visse valg til den enkelte lærers undervisning). Skolerne træffer dog også økonomiske beslutninger, politiske beslutninger mv. Herved reducerer de social kompleksitet omkring undervisningen og forbinder uddannelsessystemet med andre funktionssystemer.

Undervisning kan således forstås som social interaktion mellem lærere og elever, der sigter på at (ud)danne eleverne. Klasselokalet er den historisk udviklede institutionalisering heraf. Undervisning kan ikke implementeres som kausalt formede årsager, der lovmæssigt giver bestemte virkninger (Luhmann 2006:144). Således kan læreren ikke være sikker på, at en strategi vil føre til et givet uddannelsesresultat. Eleverne er ikke kausale systemer, dvs. trivialmaskiner, hvor et bestemt input giver bestemt output. Undervisning må formes som symbolsk betydningsmættede interaktionssystemer, der udvikler sig gennem deltagernes gensidige iagttagelser, hvilket giver dem den nødvendige kompleksitet og sprogfærdighed (Luhmann 2006:185). Skolen som organisation kan ikke beslutte alt, hvad der sker i en time. Hvordan elever 
og lærere de facto responderer og ikke responderer på hinandens ytringer er grundlæggende uforudsigeligt, og skaber en dynamik, der overhovedet karakteriserer undervisning.

\section{Empirisk undersøgelse af skriftlig undervisningsinteraktion}

Vi vender os nu mod en undersøgelse af, hvorvidt der er tegn $p a ̊$, at digitale kommunikationsmedier kan rumme et potentiale for skriftlig undervisningsinteraktion, som er anderledes/større end tidligere tiders medier. Vi går frem på den måde, at vi først forsøger at indkredse noget generelt om forskellen på den gamle og den nye mediematrice, dvs. groft sagt indkredser de kommunikationstekniske rammer for undervisning før og efter digitale mediers opståen. Der er her kun tale om grove penselstrøg, der skal berede vejen for hypoteser. Vi kan således på ingen måde gå nærmere ind på de utallige forskellige pædagogiske strømninger og måder at forholde sig til og bruge kommunikationsmedier på de sidste par tusinde år. Ja vi kan ikke engang give et fyldestgørende billede af situationen i Danmark umiddelbart før internettets komme. Hvad vi kan gøre, er blot i forlængelse af ovenstående teoretiske udredning at indkredse, hvordan undervisning typisk og helt overordnet er blev forstået og baseret på medier hidtil, og hertil hvilke nye mediemuligheder der med det digitale ser $u d$ til at føje sig til, og dernæst hvad det muligvis kan give af nye potentialer for undervisning.

Herefter vil vi langt mere konkret, men derfor også kun i bedste fald eksemplarisk, dykke ned i et aktuelt forskningsprojekt, som har sat fokus på, hvilke muligheder for skriftlig undervisningsinteraktion de digitale medier kan rumme, nemlig aktionsforskningsprojektet Socio Media Education (SME). Vi kender projektet indgående fordi vi var forskerne i projektet. SME-projektet gik over en treårig periode fra 2011-2014, hvor en gymnasieklasse og dens lærere blev påvirket gennem samtaler og fremlægning af forskningsbaseret viden (Tække og Paulsen 2013; 2016). Et vigtigt element i SME-projektet var, at klassen og dens lærere skulle anvende Twitter til skriftlig interaktion. Ikke sådan at der ikke måtte interageres mundtligt, men klassen skulle også interagere skriftligt. Vi har i anden sammenhæng redegjort omfattende for SME-projektets metodiske forudsætninger, grundlag, resultater og lignende (ibid.), hvorfor det ikke skal ske her, hvor vi blot fremhæver få uddrag fra projektet, hvor skriftligt interaktion ved hjælp af nye medier står i centrum.

\subsection{Repræsentationsmedier og interaktionsmedier}

Inden vi kaster os ud i den konkret-empiriske analyse, vil vi således først ud fra ovenstående udredninger skitsere vores konceptuelle bud på, hvad overgangen til et digitalt samfund betyder for undervisning. 
Vi har argumenteret for, at al undervisning kombinerer interaktion med forskellige muligheder for repræsentation af betydningsindhold. Efterhånden som der fra tidernes morgen til i dag er blevet udviklet mange medier fra orale, over skriftlige til de digitale, er der opstået nye muligheder for at kombinere interaktion og repræsentation og dermed skabe nye undervisningspotentialer. Repræsentation vil vi i denne sammenhæng definere som fremstilling af intersubjektivt tilgængeligt betydningsindhold i en mere eller mindre varig form, visuelt, tekstuelt eller i anden modalitet. Der kan $\mathrm{fx}$ være tale om viden, men også om falsk information eller reklamer. Når man udgiver en bog eller sætter et vejskilt op eller skriver noget på en tavle, er der tale om repræsentation af betydningsindhold i en intersubjektiv tilgængelig form. I hvert tilfælde benyttes et særegent materielt underlag til at repræsentere betydningsindhold.

Interaktion på sin side opstår, når fremstilling af betydningsindhold tager form af kommunikation frem og tilbage mellem personer, der gensidig responderer på hinandens betydningsfremstillinger (jf. overstående). Det undervisningsmæssige potentiale kan alt andet lige antages at vokse, når der benyttes medier, hvor betydningsindhold let kan bearbejdes, diskuteres, justeres etc. Forskellige kombinationer af repræsentations- og interaktionsmedier forstørrer undervisningens mulighedsrum. En tavle kan fx virke som repræsentationsmedie for et indhold, der følgende kan føres mundtlig interaktion om. Interaktionen kan bearbejde, diskutere, ændre og justere indholdet. En vægtavle er dog ikke noget godt lagringsmedie eller særlig mobil; det er til gengæld en trykt lærebog: dens mobilitet kombineret med at betydningsindholdet $\mathrm{i}$ denne står fast, gør den egnet til at repræsentere skolens omverden i skolen (når denne omverden kan antages at være relativ konstant). Ved hjælp af mediekæden: lærebogen, tavlen og skolehæfter, kan skolen indrettes, så eleverne tilegner sig viden om omverden. ${ }^{2}$ Forståelsen heraf og tilvejebringelsen kan ske interaktivt i klassen gennem mundtlig interaktion mellem lærer og elever.

Således er undervisning hidtil typisk blevet forstået og praktiseret på en måde, hvor interaktionen har fundet sted "internt" i undervisningen gennem mundtlighed, mens der er blevet knyttet an til den "eksterne" omverden dels gennem denne mundtlighed (hvor elever og lærere bl.a. har trukket på deres hukommelse om, hvad de tror, de ved om verden uden for skolen), dels gennem repræsentation i skiftlighedens format. Hertil har der, som tidligere nævnt, selvfølgelig også været et utal af undtagelser og afvigelser, som fx virksomhedsbesøg, aktioner i samfundet, udlandsrejser, forsøgsskoler osv. - men netop anskuet som afvigelser eller undtagelser fra grundnormen eller det man kan kalde for "normalskolen" - en typisk undervisning i en typisk dansk kommuneskole i det tyvende århundrede, kunne man sige. 
Med nye digitale sociale medier som Twitter og Google.doc kan der umiddelbart skabes en anderledes og mediemæssigt mere smidig kombination af interaktion og repræsentation. Interaktionen mellem elever og lærere kan udbygges, så den i højere grad også bliver skriftlig, med flere deltagelsesmuligheder, herunder også for tredje parter. Samtidig kan viden om omverdenen repræsenteres mere fleksibelt og viderebearbejdes i fællesskab, på måder hvor repræsentation og interaktion flettes mere finmasket sammen end tidligere. Dertil kan der med de digitale medier opstå mulighed for at relatere sig interaktivt til omverdenen, såvel mundtligt (fx Skype) som skriftligt (fx Twitter). En mere dynamisk omverden kan bemødes undervisningsmæssigt og dermed danne eleverne i skolen på mere kompleks vis (Paulsen og Tække 2017).

Det er vores hypotese, at meget af det, som sker med undervisning i overgangen fra et analogt baseret samfund til et digitalt, hænger sammen med et sådan skifte fra en gammel mediematrice, med dens særegne kombination af interaktion og repræsentation og perfektionering af de muligheder, der lå indenfor denne, til en ny kombination, hvis undervisningspotentiale først nu er ved at blive synligt.

\subsection{Før digitale medier: begræsnet skriftlig interaktion}

Lad os prøve at karakterisere normalsituationen før de digitale mediers opståen lidt nærmere, men stadig på et meget generelt plan. Hvordan så undervisningen typisk ud i en skoleklasse tirsdag formiddag? Selvfølgelig forskelligt alt efter om der har stået idræt eller tysk på skemaet, men lad os alligevel forsøge at beskrive en typisk situation. Vi griber igen til Luhmann for at give en karakteristik, som i det mindste siger noget om, hvordan man sociologisk og teoretisk har opfattet, hvad der typisk har været tilfældet. Således beskriver Luhmann undervisning før digitale medier sådan her: "Interaktionerne finder sted i lukkede rum, der ikke er offentlige, så distraktion fra omverden kan blive minimeret" (Luhmann 2006:131). Læreren har den autoritative magt over fortolkningen af den trykte lærebog og en væsentlig magt over undervisningsinteraktionen: "Især sikrer den rumlige afgræsning af undervisningsinteraktionen, at undervisningssystemet kan kontrollere sine egne tematikker og selv beslutte med sig selv, hvornår det begynder på, ændrer på eller afslutter temaer" (Luhmann 2006:132).

Selvfølgelig har pædagogikken været opblødt efter indførelsen af specielt tv, hvorefter det blev forbudt at slå elever, og interaktionen mellem lærer og elever blev mere dialogisk og mere ligeværdig. Disciplinen skiftede karakter, og elevernes egne erfaringer og meninger blev mere fremherskende. At specielt tv fik stor indflydelse var dog mest indirekte, da de analoge elektroniske medier med deres transparens bredt medførte krav om ligestilling, rettigheder og respekt, hvilket smittede af på skolen. Direkte betød de mest, at man via audiovisuelle 
medier kunne få reprosenteret forhold andre steder fra, $\mathrm{fx}$ en englænder, der taler sit modersmål. De fire vægge og den interaktionelle afsondrethed forblev den samme som tidligere. Selv med inddragelse af elevernes erfaringer forblev læreren den, der skulle autorisere tolkning af teksterne, som nu ofte kunne være fotokopier som læreren selv havde valgt. Formuleret i mediebegreber kan vi sammenfatte, at undervisning helt op til internettets komme blev forstået og praktiseret på den måde, at mundlig interaktion mellem lærer og elever skulle støtte elevernes tilegnelse af betydningsindhold, repræsenterende verden uden for skolen, igennem ibrugtagning af repræsentationsmedier som tavler, tekstbøger, hæfter, fjernsyn og lærerens hukommelse og vid. Interaktion med aktører uden for skolen (ved at man bevægede sig ud til disse eller inviterede disse ind på skolen eller sendte og modtog breve) har selvfølgelig også fundet sted nu og da, men har enten været eksotiske undtagelser eller begrænset i forhold til mest at vedrøre lokale aktører.

\subsection{Twitter, interaktion og interaktivitet}

Vi vender os nu mod situationen efter de digitale mediers komme, nærmere bestemt ved at kaste os ud i en analyse af uddrag fra ovenstående SME-aktionsforskningsprojekt. Vi koncentrerer os om lærere og elevers forsøg på at anvende Twitter til undervisningsmæssige formål. Først må vi dog sige lidt om Twitter og dets potentiale for interaktion og interaktivitet i forbindelse med undervisning (se Paulsen og Tække 2017 for uddybende).

Twitter er nyligt gået fra 140 tegn til 280 tegn som maksimal længde på en tweet og er bygget op således, at man kan følge andre og herved følge deres tweets. Gøres relationen gensidig, kan man følge hinandens tweets. Hertil kan man lave lister, hvorved man i sin klient på en fane eksklusivt kan følge dem på listen, hvilket kan samle interaktionen i en klasse. Mere nærliggende er, at man i forskellige fag bruger forskellige hashtags (\#) til at centrere interaktionen. Også indenfor de forskellige fag kan man via hashtags centrere interaktionen om specifikke emner og underemner. I interaktionen kan man via tags (@) rette sin henvendelse til andre bidragydere eksempelvis i interaktionen centreret om et hashtag. Dette er en fordel, da der ikke er lineær kohærens i en twittertråd, men kun nonlineær kohærens. Den nonlineære kohærens kan for en ikkeøvet Twitterbruger virke forvirrende, da forskellige bidrag til trådens andre bidrag tidsmæssigt tikker ind ikkekronologisk. De forskellige klienter giver også forskelle $i$, hvor hurtigt bidrag tikker ind. Men for den trænede Twitterbruger er brugen af tags, inden for den med hashtags centrerede interaktion, tilpas kompleksitetsreducerende, til at interaktionen kan forløbe meningsfuldt. Den skriftlige interaktion giver mange af den sprogligt baserede mundtlige og skriftlige interaktions muligheder (inden for de mulige digitale tegn), samt de der henfører sig til det digitale me- 
die. Således sker interaktionen nærsynkront, hvor man iagttager hinandens ytringer og selekterer forståelse, som kan meddeles via egne ytringer (tweets). Twitter giver således rum for konversationel interaktivitet. At anvende hashtags i sin interaktion giver hertil registrerende interaktivitet, således at man via hashtagget deklarerer sit ytringsbidrag til en meningskontekst. Twitter kan videre anvendes til konsultativ interaktivitet, hvor en elev eksempelvis hjemmefra under lektielæsning (gen)finder tweets, således at den skriftlige undervisningsinteraktion kan anvendes som fælles noter.

Den mundtlige interaktion i en skoleklasse kan med et medie som Twitter nu også bestå i skriftlig interaktion sammenflettet med den mundtlige. For blot at give et eksempel (se Tække og Paulsen 2013 for mange flere): Læreren kan stille et spørgsmål, mundtligt eller skriftligt, og alle elever i klassen kan så svare på Twitter, mens læreren på digital tavle viser svarene og responderer på disse med opfordring til dialog om svarene. Dernæst kan svar "tages" med videre i fx gruppearbejder som brainstorm. En sådan anvendelse udviser deltagelsesmulighederne fremfor en situation, hvor fx eleverne forventes kun at svare mundtligt: her er det typisk ikke alle, der rækker fingrene op, og kun én af gangen kan svare, og typisk er det også kun relativt få, der de facto kommer til orde.

Således kan ibrugtagning af Twitter udvide interaktionens rækkevidde, da Twitter både fungerer som interaktion- lagrings- og genfindingsmedie. Hertil foregår den skriftlige interaktion uden lyd, hvorfor elever kan svare på spørgsmål samtidig. Elever kan også under fx mundtlige fremlæggelser eller film interagere om fremlæggelsen/filmen. At der er tale om interaktion, betyder, at alle kommunikative metaniveauer refleksivt kan italesættes. Dvs. at enhver kan begynde en kommunikation om den verserende kommunikation (nu skal vi tale pænt, er det rigtigt, det læreren siger, jeg kan se på Wikipedia...). Det sociale produceres og reproduceres på mikroplanet i interaktionen, hvor meningsforslag hhv. accepteres og negeres, så selve strukturen og kulturen løbende udvikles. Man kan tale om en fordobling af det interaktive rum. Ved at inkludere den skriftlige interaktion i undervisningen og i den sociale dannelse og organisering af skoleklasser bliver også skolen og undervisningen fordoblet. Går vi tilbage i tid, eksisterede muligheden for omfattende skriftlig interaktion og interaktivitet stort set ikke, men det gør den nu.

\subsection{Skriftlig interaktion i klassen}

Et eksempel på dette var, da dansklæreren i ovenævnte SME-projekt bad eleverne om at anvende Twitter, mens de så filmen "Kundskabens træ". I følgende interview-uddrag reflekterer eleverne efterfølgende over, hvordan det virkede at interagere skriftligt, mens de så film. 
Elev 1: Da vi så film, så sad han [læreren] og stilede spørgsmål på Twitter, som vi skulle svare på. Det synes jeg var rigtig godt.

Forsker: Hvorfor var det godt?

Elev 1: Fordi, så fik man det med, hvis der var noget nødvendigt ... noget man ikke lige opfangede eller sådan noget...

Elev 2: ... I stedet for at huske det til efter filmen. Det kan jo være relativt svært at huske en hel film bagefter.

Forsker: Vi observerede jo også den time med filmen, og vi var meget imponerede over flere af jeres evner til både at skrive i Twitter og følge med i filmen. Var det ikke svært?

Elev 1: Nej, egentlig ikke, man mister bare lige nogle få sekunder, fordi det kører samtidig. Det man misser, det er bare lige, hvordan billedet var.

SME-elevinterview 2/11 - 2011, side 2 .

Elev: det ville være mere afslappende uden Twitter, men man ville nok ikke få så meget ud af filmen uden - man mister lidt, men man lægger mere mærke til det læreren vil have.

SME-elevinterview 1 2/11 2011, side 10.

Elev: Hvis vi nu skriver et eller andet positivt om filmen, eller hvad sker der nu og sådan noget dér, så kan man sådan tænke lidt mere over det og sætte sig noget mere ind i filmen. Så der kommer flere synsvinkler ...

SME-elevinterview 1. D. 10/1 2012, side 5.

Som det fremgår, virker den parallelle skriftlige interaktion på Twitter supporterende i relation til såvel dannelsen af undervisningsmæssig opmærksomhed og forståelse i processen, som til styrkelsen af hukommelse og produktionen af fælles noter. Når eleverne skal relatere sig til lærerens og de andre elevers spørgsmål, bliver det mere sandsynligt, at eleverne holder fagligt fokus. Samtidig kan den enkelte elev stille spørgsmål, hvis der er forståelsesmæssige problemer, der hæmmer dennes muligheder for at følge med i nye udviklinger og forstå, hvad det er, der foregår i filmen (eller i et hvilken som helst andet undervisningsforløb). Når eleven i denne medieundervisning ser ned på skærmen, bliver hun ikke distraheret af andre applikationer, men drages tilbage til undervisningsinteraktionen. Opmærksomheden hjælpes også på vej, ved at læreren sidder nede blandt eleverne med det udsyn og den viden dette giver om elevernes adfærd - og dertil eksemplarisk tager del i den kollektive behandling af den sag, undervisningen omhandler (Tække og Paulsen 2013). Der blev udvekslet i alt 214 tweets under filmen, der blev set over to dage. Læreren sad nede blandt eleverne, der på dette tidspunkt kun havde anvendt Twitter i lidt over en måned og stadig ikke beherskede tags, hvilket gør det svært helt af følge kohærensen. Den bid der er valgt ud her viser slutningen af første time og begyndelsen af anden time. Udover interaktion og metakommunikation ses også et eksempel på konsulterende interaktivitet, hvor læreren 
d. 29/9 spørger ind til noget som elev 1 skrev d. 28/9. Når vi ser elev 1 svare læreren, ses det også, at klassen kun lige er ved at kunne mestre hashtags.

\begin{tabular}{|c|c|c|}
\hline \begin{tabular}{l|}
$2011-09-28$ \\
$11: 08: 18$
\end{tabular} & Elev 1 & $\begin{array}{l}\text { \#1 omadansk - Handlingen er bundet til børnenes ud- } \\
\text { vikling - både fysisk og psykisk. }\end{array}$ \\
\hline $\begin{array}{l}2011-09-28 \\
11: 08: 55\end{array}$ & Elev 1 & \#1 omadansk - Hvor gamle er børnene i starten af filmen? \\
\hline $\begin{array}{l}2011-09-28 \\
11: 09: 17\end{array}$ & Elev 2 & \#1 omadansk ca 13 \\
\hline $\begin{array}{l}\text { 2011-09-28 } \\
11: 10: 10\end{array}$ & Elev 2 & \#1 omadansk hvem er med i den "såkaldte" pigegruppe? \\
\hline \begin{tabular}{l|}
$2011-09-28$ \\
$11: 12: 14$
\end{tabular} & Elev 3 & $\begin{array}{l}\text { \#1omadansk fordi de er liderlige, og de gerne vil kysse } \\
\text { uden de andre ser på:) }\end{array}$ \\
\hline \begin{tabular}{l|}
$2011-09-28$ \\
$11: 13: 19$
\end{tabular} & Elev 3 & $\begin{array}{l}\text { \#1 omadansk hvorfor vil han ikke få nogen støtte hjemme- } \\
\text { fra hvis han gjorde en pige gravid }\end{array}$ \\
\hline \begin{tabular}{l|}
$2011-09-28$ \\
$11: 14: 59$ \\
\end{tabular} & Elev 4 & \#1 omadansk fordi forældrene er meget strikse \\
\hline $\begin{array}{l}2011-09-28 \\
11: 16: 59\end{array}$ & Elev 5 & $\begin{array}{l}\text { \#1omadansk eller for at skræmme børnene til ikke at } \\
\text { dumme sig }\end{array}$ \\
\hline \begin{tabular}{l|}
$2011-09-28$ \\
$11: 23: 08$
\end{tabular} & Elev 4 & 1\#omadansk hvad er det der sker med Elin? \\
\hline $\begin{array}{l}2011-09-28 \\
11: 30: 00\end{array}$ & Elev 6 & \#1 omadansk hvem er trl \\
\hline \begin{tabular}{l|}
$2011-09-28$ \\
$11: 30: 15$
\end{tabular} & Elev 4 & \#1 omadansk hvad er det der sker med Elin? \\
\hline \begin{tabular}{l|}
$2011-09-28$ \\
$11: 31: 33$ \\
\end{tabular} & Elev 7 & \#1 omadansk hvad betyder TRL?? \\
\hline \begin{tabular}{l|}
$2011-09-28$ \\
$11: 31: 44$
\end{tabular} & Elev 8 & \#1 omadansk Elin evt.? \\
\hline $\begin{array}{l}2011-09-28 \\
11: 31: 47 \\
\end{array}$ & Elev 9 & \#1 omadansk Transportabel rejse luder \\
\hline \begin{tabular}{l|}
$2011-09-28$ \\
$11: 32: 49$
\end{tabular} & Elev 9 & \#1 omadansk hvorfor bliver mona kaldt klister \\
\hline $\begin{array}{l}2011-09-28 \\
11: 33: 44\end{array}$ & Elev 10 & $\begin{array}{l}\text { \#1 omadansk Det er fordi de mener hun er klistret til dem, } \\
\text { hun følger efter dem. }\end{array}$ \\
\hline \begin{tabular}{l|}
$2011-09-28$ \\
$11: 33: 57$ \\
\end{tabular} & Elev 9 & $\# 1$ omadansk godt $\mathrm{t}$ \\
\hline \begin{tabular}{l|}
$2011-09-28$ \\
$11: 36: 11$ \\
\end{tabular} & Elev 8 & \#1 omadansk nu bliver det mørkt og hvad sker der så xD \\
\hline $\begin{array}{l}2011-09-28 \\
11: 36: 11\end{array}$ & Elev 7 & \#1 omadansk hvad sker der? \\
\hline
\end{tabular}




\begin{tabular}{|c|c|c|}
\hline \begin{tabular}{|l|} 
2011-09-28 \\
$11: 36: 15$ \\
\end{tabular} & Elev 9 & \#1 omadansk så bliver det mørkt, og HVAD sker der så?!?! \\
\hline \begin{tabular}{|l|} 
2011-09-28 \\
$11: 37: 39$ \\
\end{tabular} & Elev 10 & $\begin{array}{l}\# 1 \text { omadansk 1time } 12 \text { minutter } 6 \text { sekunder spillet af fil- } \\
\text { men;-) }\end{array}$ \\
\hline \begin{tabular}{|l|} 
2011-09-29 \\
09:16:32 \\
\end{tabular} & Lærer & $\begin{array}{l}\text { \#1 omadansk Jeg sidder på lærerværelset og glæder mig til } \\
\text { at se "Kundskabens træ" færdig med } 1 \text { øa:- }\end{array}$ \\
\hline \begin{tabular}{|l|} 
2011-09-29 \\
10:16:43 \\
\end{tabular} & Lærer & \#1omadansk - kan du yddybe din pointe Elev 1 ? \\
\hline $\begin{array}{l}\text { 2011-09-29 } \\
10: 16: 45\end{array}$ & Elev 11 & \#1 omadansk ja det er da lidt træls for ham \\
\hline \begin{tabular}{|l|}
$2011-09-29$ \\
$10: 17: 37$
\end{tabular} & Lærer & \#1 omadansk - hvorfor vælger hun Gert fra? \\
\hline \begin{tabular}{|l|} 
2011-09-29 \\
10:18:07 \\
\end{tabular} & Elev 5 & \#1 omadansk - Men der skal jo være nogen der sidder over \\
\hline $\begin{array}{l}\text { 2011-09-29 } \\
10: 19: 42\end{array}$ & Elev 1 & $\begin{array}{l}\text { Jamen det kan du tro. Det betyder bare, at vi følger nogle } \\
\text { karakteriserede episoder, som passer til de forskellige be- } \\
\text { givenheder. }\end{array}$ \\
\hline \begin{tabular}{|l|} 
2011-09-29 \\
10:19:51 \\
\end{tabular} & Elev 12 & $\begin{array}{l}\text { \# 1omadansk Ham knægten som gik med hunden, var det } \\
\text { hjemme hos ham de holde festen? }\end{array}$ \\
\hline \begin{tabular}{|l|} 
2011-09-29 \\
10:19:57 \\
\end{tabular} & Lærer & $\begin{array}{l}\text { \#1 omadansk Vær opmærksom på Niels Oles reaktion - } \\
\text { når han om lidt ser de fremkaldte billeder! } \\
\end{array}$ \\
\hline \begin{tabular}{|l|} 
2011-09-29 \\
10:19:57 \\
\end{tabular} & Elev 11 & \#1 omadansk han sidder jo over hele tiden nicholas \\
\hline $\begin{array}{l}\text { 2011-09-29 } \\
\text { 10:20:07 }\end{array}$ & Elev 1 & $\begin{array}{l}\# 1 \text { omadansk Jamen det kan du tro. Det betyder bare, at } \\
\text { vi følger nogle karakteriserede episoder, som passer til de } \\
\text { forskellige begivenheder. }\end{array}$ \\
\hline
\end{tabular}

Såvel faglige som sjove regibemærkninger fletter sig ind i hinanden og klassen virker som et fortolkningsfællesskab, der hygger sig, mens de afkoder filmen. Og da Twitter samtidig er et lagrings- og genfindingsmedium, virker interaktionen senere som fælles noter.

Undervisningsfællesskabet, der anvender skriftlig interaktion på denne måde, er i stand til at interpellere eleverne og derved opretholde opmærksomhed, aktivitet, deltagelse og arbejdsdisciplin. Samtidig sandsynliggør observationer og interview med lærere og elever, at flere elever er inkluderet i undervisningsinteraktionen, når denne ikke kun foregår mundtligt, men også skriftligt (Tække og Paulsen 2013). Empirien fra SME tyder på, at den skriftlige interaktion også bidrager til at få mere kvalitet ind i undervisningen (ibid). Man kan dog ikke bare uden at opøve kompetencer og dannelse udnytte den skriftlige interaktions muligheder. Dette blev tydeligt, da SME-klassens lærere prøvede at anvende de udviklede undervisningsdesign i andre klasser, hvor de ikke opnåede samme succes (ibid). 
I SME-klassen fik de lærere der ofte anvendte Twitter, såvel ifølge egne udsagn som ifølge elevernes udsagn, en god tillidsrelation til eleverne. De opnåede en større og mere indgående viden om eleverne, hvilket hjalp dem til en bedre klasserumsledelse end de selv syntes at have oplevet før i andre klasser (ibid). Efter elever og lærere i løbet af det første år opnåede de fornødne kompetencer i skriftlig interaktion via Twitter, begyndte lærerne at give eleverne lektiehjælp om aftenen. Eleverne siger i interview herom (ibid):

Forsker: Synes du, at det er en fordel, at man på den måde, når man sidder derhjemme, kan få noget hjælp?

Elev: Det synes jeg, for det er jo ikke altid, at ens forældre kan hjælpe én med alle fagene. Så synes jeg, det er lækkert, at man bare kan skrive til læreren, selvom man sidder derhjemme og ikke skal vente til dagen efter og prøve at finde vedkommende.

Ifølge lærerne bevirkede den skriftlige interaktion, at de havde bedre føling med eleverne og derfor bedre kunne følge op på de enkeltes trivsel og faglige arbejde.

\subsection{Skriftlig interaktion med omverden}

I SME-eksperimentet skulle lærere og elever fra andet år arbejde med at kultivere kontakten mellem klassen og dens omverden for at etablere dialog med dannelsespersoner. Kontakten med omverdenen skulle kvalificere undervisningsinteraktionen i stedet for at trække opmærksomheden væk fra den. Hertil skulle kontakten berige informationssituationen med vinkler og perspektiver ud over, hvad en lærer vil kunne formå på egen hånd (gennem traditionelle repræsentationsmedier). Overordnet set skulle denne strategi kultivere klassen til at kunne arbejde i en modus adækvat med det nuværende mediemiljø.

Et eksempel var da dansklæreren optog kontakt til den danske forfatter Kasper Anthoni. Klassen læste en af hans digtsamlinger og stillede ham spørgsmål gennem to Twitter-sessioner. Ifølge læreren plejer elever på gymnasiet ikke at vise interesse for digte, men dette forhold blev ændret af kontakten med en ægte forfatter. Også ifølge eleverne var det spændende og engagerende med kontakten (Tække \& Paulsen 2016):

Elev 1: Det synes jeg var en helt anderledes måde at analysere digte i hvert fald. En meget bedre måde synes jeg selv.

Elev 2: Ja, når vi har forfatteren, som vi selv kan spørge, hvis der nu er noget, vi ikke rigtig forstår ved digtet og så spørge ham, hvad har du ment, da du har skrevet det. Så kan han jo så komme med et tweet omkring det.

Elev 3: Det hjælper os med fortolkningen. Hvis jeg nu spørger om hvordan han kom på idéen, så fortæller han at han fik en følelse, og så bliver det også nemmere, for så kan vi fortolke digtet. Jeg synes at det er godt. 
Interaktionen med forfatteren er eksemplarisk som eksempel på hvordan klassen med den skriftlige interaktion kan bevæge sig ud af et ellers lukket klasserum på en undervisningsrelevant måde. Læreren er den der tager ansvar for situationen og organiserer den. Læreren har således etableret kontakten og lavet aftalen med digteren, hjulpet eleverne med at læse digtene på forhånd og med at formulere gode spørgsmål og sørget for organisation i grupper. Disse anstrengelser er givet godt $\mathrm{ud}$, når man kigger på elevernes efterfølgende engagement vakt til live i kontakt med en rigtig forfatter over Twitter (Tække \& Paulsen 2016).

Gennem interaktionen med forfatteren ændrede digtene betydning for eleverne. Sat på spidsen opfattede eleverne digte, læreren kom med, som en skoleintern genstand. En del af de elever, som gik i SME-klassen, beskæftigede sig ikke med lyrik uden for skolen. Digte var ikke en del af deres virkelighed. For dem var lyrik noget skoleopfundet. Men i interaktionen med forfatteren ændrede dette sig. Lyrikken får virkelig betydning. Gennem interaktionen med forfatteren blev der skabt forbindelse mellem elevernes livsverden og en verden, som rummer lyrik. Dermed blev dansk til et dannelsesfag, dvs. til en måde at forholde sig til verden på, åbnende verden op for eleverne og åbnende eleverne op for verden. Efterfølgende blev nogle elever venner med forfatteren på Facebook og begyndte at modtage lyrikrelaterede opslag i deres newsfeed. Ligeledes støttede eleverne på de sociale medier en ny digtsamling, forfatteren udgav noget tid efter. Endelig søgte nogle elever hjælp fra forfatteren, da de skulle til eksamen. Det er uvist, hvor meget dette betyder. Generelt indikerer det dog et undervisningspotentiale ved de nye medier, som må være stort, hvis lærere i alle fag begynder at indlede fagligt relevante interaktioner med tredjeparter uden for skolen: mennesker i andre lande, politikere, flygtninge, andre unge, forskere, aktivister osv.

Lad os se nærmere på et uddrag fra twittersessionen, hvor klassen dannede et skriftligt baseret interaktionssystem med forfatteren:

Kasper Anthoni @AnthoniKasper: \#2omadansk Så er jeg online ...

Elev 1: \#2omadansk @AnthoniKasper vi arbejder med digtet "korsør"- vi har derfor nogle spørgsmål, som vi håber du vil hjælp med at svare på.

Elev 1: \#2omadansk @AnthoniKasper første spørgsmål lyder: 1.har du et forhold til Korsør? Og hvordan kan det være at Korsør står med småt?

Kasper Anthoni @AnthoniKasper: \#2omadansk Jeg skal gøre mit bedste.

Kasper Anthoni @AnthoniKasper: @Elev1 \#2omadansk Korsør står med småt, da alt i delfinbogen står med småt. Kendte en pige kortvarigt, der var fra Korsør

Elev 2: \#2omadansk Er digtet om en tidligere kvinde?

Kasper Anthoni @AnthoniKasper: @Elev2 \#2omadansk Det er inspireret af en oplevelse fra det virkelige liv, ja.

Elev 1: \#2omadansk 2. Hvad mener du i digtet med at "jeg'et" ikke kan vende tilbage på grund af sådan en venlig afsked? 
Kasper Anthoni@AnthoniKasper: @Elev1 \#2omadansk Nogle gange kan oplevelser være så unikke, at de ikke kan gentages. De vil i hvert fald ikke leve op til 1. gang.

Kasper Anthoni @AnthoniKasper: @Elev1 \#2omadansk Og måske har digtets 'jeg' svært ved at binde sig?

Elev 1: \#2omadansk@AnthoniKasper 3.Var det en tilfældighed at du mødte.

Elev 3: \#2omadansk @AnthoniKasper 1. Spørgsmål: I digtet Korsør, hvad symboliserer det røde rum?

Elev 1: @Elev2 \#2omadansk Er det ikke det røde rum på en færge?

Elev 4: \#2omadansk Hej Kasper :-) Spørgsmål fra vores gruppe lyder således: Hvad mener du med sine røde rum?

Kasper Anthoni @AnthoniKasper: @Elev1 \#2omadansk Hvis vi antager at 'jeg' er jeg, så nej. Det røde rum skal læses i overført betydning. Varme, omsorg, tryghed.

Man ser, at eleverne lidt inde i 2.g. mestrer såvel hashtags som tags i interaktionen. Hertil kan man se, at de har forberedt spørgsmål gruppevis. Forfatteren bliver herved en del af undervisningsinteraktionen. Klassen udgør stadig en social entitet, et undervisningsfællesskab, men set som interaktionssystem kan det udvides med deltagere udefra, der befinder sig andre steder (Tække og Paulsen 2016).

Når andre mennesker end eleverne og lærerne gennem internettet bliver integreret i undervisningsinteraktionen, forandrer det den undervisningsform, der har eksisteret siden trykkepressen, og som har domineret almindelig klasserumsundervisning. I stedet for lukket klasserumsundervisning mellem lærere og elever, kan vi iagttage et åbent interaktionssystem, hvori personer udefra deltager og bidrager til undervisningsinteraktionen. På daglig basis kan eleverne nu møde mennesker med andre perspektiver, synsvinkler, erfaringer, viden, sprog og reaktioner. Læreren og lærebogen er ikke længere eneste informationskilde og tolkningsmagt, igennem hvilken eleverne kan dannes. $\mathrm{Nu}$ kan læreren også konfrontere eleverne med samtidige, udefrakommende synspunkter og perspektiver, som de med lærerens hjælp kildekritisk forhold-

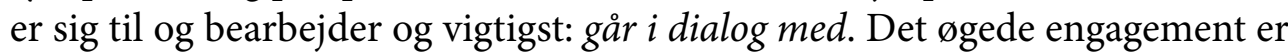
formentlig en følge af det virkelighedsmøde, eleverne oplever, når skolearbejdet implicerer nærsynkron kontakt med virkelige mennesker (andetheder) i autentiske situationer. Selve mødet består i en skriftlig interaktion (men kan også ske mundtligt remedieret igennem medier som Skype) og ville ellers kun optræde undtagelsesvist. Hertil er den skriftlige interaktion nemmere at præge mod sagsdimensionen, end hvis den finder sted mundtligt ansigt til ansigt. Som eksempel på dette blev forfatteren inviteret på besøg i klassen på et tidspunkt efter den skriftlige interaktion havde fundet sted. Men her virkede elever og forfatter generte overfor hinanden - den sociale situation overlejrede den fælles optagethed af sagen: 
Forsker: Gav det mere, at han kom og var her i klassen, end hvad I egentlig fik ud af at tweete med ham?

Elev 2: Det var vel mere bare en digtoplæsning, da han kom til klassen.

Elev 1: Ja, det var bare lige at møde ham personligt også. Lige prøve en digtoplæsning også.

Forsker: Så rent fagligt i forhold til digtet, der var det egentlig fint nok bare med Twitter?

Elev 1: Ja

Elev 3: Det er faktisk lige før, at jeg fik mest ud af, at det bare var på Twitter, synes jeg. For dengang han kom op i klassen, der læste han egentlig mest bare sine digte op, og der havde vi allerede snakket om dem inden.

Anvendelsen af den skriftlige interaktion på ovenstående måde ser ud til at kunne øge den faglige orientering, da man ikke behøver at tage stilling til den andens krop og følelsesmæssige udtryk og spejle denne, samt selv at reflektere over den andens iagttagelse af ens krop og fremtoning. Selvfølgelig skal den skriftlige interaktion ikke erstatte den mundtlige, hvor man har hinandens kroppe. Det er heller ikke intentionen, at man ikke skal møde andethed i form af andet end skriftlig interaktion. Intentionen i det konkrete forsøg var blot at eksperimentere med at udnytte det nye mulighedsrum undervisningsmæssigt. Fordelene er eksempelvis muligheden for at binde dannelsespersoner til undervisningen og derved gøre den vedkommende, informativ og opdateret (mange elever klager over gamle utidssvarende bøger, artikler og cases) og dermed engagerende. Hertil bliver det indhold, der skabes i undervisningen mere fagligt orienteret, mulig at lagre og genfinde og herved mulig at forædle og eksempelvis lægge ind i en wiki mhp. fx fornyet kontakt til omverdenen (Tække \& Paulsen 2013, 2016).

Når eleverne ikke "lykkes" bedre i det fysiske møde med forfatteren, så afspejler det dog også, at de to møder, det mundtlige og det skriftlige, i nævnte SME-forsøg nok ikke er didaktiseret tilstrækkeligt sammenhængende. Og endelig antyder det måske en dannelsesmæssig begrænsning: selvom elever bliver nok så fagligt engagerede i det skriftlige møde, så er der ingen garanti for, at dette engagement kan fortsættes i en "mundtlig verden"; snarere tværtimod: her mødes fremmede kroppe, hvilket ingen af parterne synes at være tilstrækkeligt forberedt på. Mundtlighed og skriftlighed rummer forskellige mødebetingelser.

\section{Konklusion}

Vi har i artiklen argumenteret for, at man forud for de digitale medier især har forstået og praktiseret klasseundervisning som mundtligt baserede interaktionssystemer, støttet af ibrugtagning af repræsentationsmedier som tekstbogen og tavlen. Videre har vi undersøgt, om og hvordan digitale medier kan 
åbne for, at undervisningsinteraktionssystemer i højere grad end tidligere både kan være mundtlige og skriftlige, og hvad det i så fald indebærer af nye/ anderledes potentialer. Undersøgelsen er faldet i to dele.

1) En konceptuel undersøgelse, hvor vi teoretisk har vist, at undervisningsinteraktion ikke nødvendigvis kræver gensidig iagttagelse af andre deltageres kroppe, men principielt kan forløbe udelukkende skriftligt. Teoretisk vil det sige, at et større antal alt andet lige kan blive deltagende og hertil, at de kan betjene sig af de interaktivitetsmæssige fordele skriften har frem for den mundtlige tale. I den mundtlige tale forsvinder ord så snart de er udtalt, hvortil de ikke efterfølgende kan kopieres og viderbearbejdes, lagres og genfindes i materiel manifest forstand. På den anden side har vi også antydet undervisningsmæssigt vigtige aspekter ved det mundtlige, uden at vi dog er gået $\mathrm{i}$ dybden med disse. Konceptuelt har vi således kun sandsynliggjort, at undervisningsinteraktionssystemer kan baseres på skrift i digitale medier og dertil kombineres med mundtlighed og et væld af repræsentationsmedier.

2) Dernæst har vi fremlagt en empirisk undersøgelse, hvor vi har set på nogle af de fordele, som skriftlig interaktion kan give i digitale medier i relation til klasseundervisning. Et eksempel er, at elever kan deltage i undervisningen hjemmefra og at de ligeledes kan drage nytte af undervisningsinteraktionssystemet udenfor skoletiden, når de laver lektier. Et andet eksempel er det samlende fokus, der opnås, når alle elever iagttager samme skriftlige interaktionstråd, der trækker elevernes bidrag sammen i en strøm af observationer, spørgsmål, svar, metakommunikation mv. som vi bl.a. har set i forbindelse med film-case. En sådan skriftlig interakion er ikke bare væk efter interaktions-systemet ophører med at eksistere, men kan tilgås igen som fælles noter der kan arbejdes videre med i forskellige mediekæder. Sidst skal nævnes, at undervisningsinteraktionssystemet både kan udvides, så det inddrager udefrakommende personer, og indskrænkes til mindre netværk, der arbejder parallelt.

Samlet kan vi pege på, at skriftlig interaktion er muligt, især med digitale medier, og at der hertil knytter sig et undervisningsmæssigt potentiale, som vi dog kun har indkredset tentativt. Videre undersøgelser må afdække mere omfattende. Hvis det vi har lagt frem holder stik, kan vi konkludere, at der bør ske en justering af, hvad der grundlæggende forstås ved undervisning. 


\section{Noter}

1 Vi er klar over, at den faktiske skolehistorie er langt mere broget og kompliceret. Hvad vi argumenterer for i artiklen er kun, at den grundlæggende opfattelse af undervisning før digitale mediers opdukken lagde op til mundtlig interaktion i et klasselokale og heri ibrugtagning af repræsentationsmedier som fx en lærebog. Der har de facto været utallige skolehistoriske undtagelser og afvigelser fra denne grundnorm: fx ekskursioner og studieture, ligesom der fx har været skabt reformpædagogiske og projektpædagogiske forsøg og skoleformer, der har forsøgt at institutionalisere anderledes opfattelser af, hvad undervisning kan og bør være.

2 Ved mediekcede forstår vi samspillet mellem flere medier, fx leder klassen efter relevante websites som de tweeter til et fælles hashtag, hvor siderne igen via Twitter udsættes for kildekritik, hvorefter man mundtligt diskuterer formidlingsstrategi mhp. repetition og den viden der er indhentet indføres i en wiki eller på en google-side.

\section{Litteratur}

Biesta, G. (2006). Beyond Learning - democratic Education for a Human Future. London: Paradigm Publishers.

Biesta, G. (2014). Den smukke risiko i uddannelse og padagogik. Århus: Forlaget Klim. Bourdieu, P. (2000). Cultural Reproduction and Social Reproduction. Pp. 56-68 in R. Arum and I. Beattie (Eds.) The Structure of Schooling: Readings in the Sociology of Education. McGraw-Hill Higher Education.

Drejer, C. M. (2014). Kampen om eleven - Hvordan skoler skaber elever. København Unge Pædagoger.

Finneman, N.O. (2005). Internettet i mediehistorisk perspektiv. Frederiksberg: Forlaget Samfundslitteratur.

Foucault, M. (2002): Overvågning og straf. Frederiksberg: Det lille forlag [1975].

Gitz-Johansen, T. \& Thomsen, P. T. (2014). Diversitet. I Dorf, H. \& Rasmussen, J. (2014). Podagogisk Sociologi. København: Hans Reitzels Forlag.

Goffman, E. (1990 [1959]). The presentation of self in everyday life. London: Penguin Books.

Jakobsen, K. A. (2016). Etter Charlie Hebdo - Ytringfrihetens krise i historisk lys. Trondheim: Forlaget Press 2016.

Jensen, Jens F (1999). 'Interactivity' - Tracking a New Concept in Media and Communication Studies. I Mayer. Paul A. 1999. Computer Media and Communication. Oxford uni. Press GB. P. 160-188.

Luhmann, Niklas. 2006: Samfundets uddannelsessystem. Hans Reitzels Forlag. København. [2002].

Luhmann, Niklas 2000: Sociale systemer. Hans Reitzels Forlag. Opr. 1984 Soziale Systeme.

Luhmann, Niklas 1999: Die Gesellschaft der Gesellschaft. Suhrkamp taschenbuch wissenschaft [1997].

Luhmann, N. (1993 [1991]). Barnet som medie for opdragelsen. I Loring Samtale Organisation. (red. Cederstrøm, J., Qvortrup, L. Og Rasmussen, J.). København: Unge Pædagoger. pp. 161-190. 
Meyrowitz, Joshua (1985): No Sence of Place: The Impact of Electronic Media on Social Behavior. New York: Oxford Uni. Press.

Paulsen M. \& Qvortrup L. (2007). Luhmann og Dannelse. København: Unge Pædagoger.

Qvortrup, L. (1993). Skolen som kommunikation. I bogen: Læring Samtale Organisation. København: Unge Pædagoger.

Saussure, Ferdinandde de (1966). Course in General Linguistics. New York: The Phil. Library, Inc.

Sutton, Leah A. (1999). Interaction. EMC 703. Arizona State University. Spring, 1999.

Tække, J. og Paulsen, M. (2016). Undervisningsfollesskab og loeringsnetvoerk i det digitale samfund. København: Forlaget Unge Pædagoger.

Tække, J \& Paulsen, M. (2014). Hybridisation of Education : leaving the Echo room.. Paper presented at Hybrids - Observed with Social Systems Theory. Dubrovnik, Kroatien.: http://pure.au.dk/portal/files/74830460/Hybridisation_of_Education_ Taekke_og_Paulsen_2014.pdf

Tække, J og Paulsen, M. (2013). Sociale medier i gymnasiet - mellem forbud og ligegyldighed. København: Forlaget Unge Pædagoger.

Tække, J. \& Paulsen, M. (2009). Om den uformelle (mis)brug af medier i det formelle uddannelsessystem. I Mediekultur vol 46, Journal of media and communication research.

Tække, J. (2006a). Luhmann og medieteori. i Tække, J. (rad): Luhmann og erkendelse. København: Unge Pædagoger.

Tække, J. (2006b): Mediesociografi. København: Innovative Communication (InC). http://pure.au.dk/portal/files/17825022/mediesociografi

Tække, J. (2002): "Cyberspace as a Space parallel to geographical space" in Virtual space: The spatiality of virtual inhabited $3 D$ worlds. Lars Qvortrup (Ed), Springer Publishers, 2002 (p. 25-42). 